\title{
Reconciling Theory and Doctrine in First Amendment Jurisprudence
}

\author{
Robert Post $\uparrow$
}

\section{TABLE OF CONTENTS}

Introduction.

I. Laying the Groundwork: Justice Holmes' Landmark Opinions .....2356

II. The First Amendment and the Marketplace of Ideas .........................2363

III. The First Amendment and Democratic Self-Government ................2366

IV. Reconciling First Amendment Theory and Doctrine .......................2369

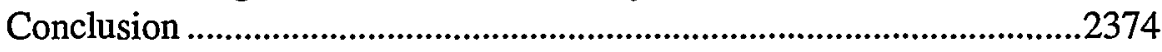

Copyright (C) 2000 Robert C. Post. California Law Review, Incorporated (CLR) is a California nonprofit corporation. CLR and the authors are solely responsible for the content of their publications.

$\dagger$ Alexander F. and May T. Morrison Professor of Law, School of Law, University of California, Berkeley (Boalt Hall). 
[Vol. 88:2353 


\title{
Reconciling Theory and Doctrine in First Amendment Jurisprudence
}

\author{
Robert Post
}

The twentieth century has seen the birth and development of the doctrine of the First Amendment's free speech clause. In its current state, freespeech jurisprudence is hampered by coexisting but conflicting First Amendment theories and doctrines. In this Essay, Professor Post examines these conflicts. He traces the development of two primary First Amendment theories: the theory of the marketplace of ideas, exemplified by Justice Holmes' dissenting opinion in Abrams v. United States; and the theory of democratic speech, articulated most notably by Alexander Meiklejohn. After discussing the doctrinal implications of these theories and noting that courts have not followed either theory consistently, Professor Post suggests that First Amendment jurisprudence could be rendered more coherent if First Amendment theories were to be ordered according to a "lexical priority" that will illuminate what is at stake in the conflict between theories and how such conflicts may be settled.

\section{INTRODUCTION}

The simple and absolute words of the First Amendment float atop a tumultuous doctrinal sea. The free speech jurisprudence of the First Amendment is notorious for its flagrantly proliferating and contradictory rules, its profoundly chaotic collection of methods and theories. ${ }^{1}$ Yet, strange to say, those fluent in the law of free speech can predict with reasonable accuracy the outcomes of most constitutional cases. It seems that what is amiss with First Amendment doctrine is not so much the absence of common ground about how communication within our society ought constitutionally to be ordered, as it is our inability to formulate clear explanations and coherent rules capable of elucidating and charting the contours of this ground.

First Amendment doctrine veers between theory and the exigencies of specific cases. The function of doctrine is both to implement the objectives

1. See generally Glen O. Robinson, The Electronic First Amendment: An Essay for the New Age, 899 Duke L.J. 966 (1998); Frederick Schauer, Codifying the First Amendment: New York v. Ferber, 1982 Sup. CT. REv. 285. 
attributed by theory to the Constitution and to offer principled grounds of justification for particular decisions. Doctrine becomes confused when the requirements of theory make little sense in the actual circumstances of concrete cases, or when doctrine is required to articulate the implications of inconsistent theories. First Amendment doctrine has unfortunately suffered from both these difficulties.

In a remarkable series of opinions in 1919, Justice Oliver Wendell Holmes virtually invented both First Amendment theory and First Amendment doctrine. He advanced the theory of the marketplace of ideas, and he demonstrated how doctrine would have to evolve to correspond to this new theory. Soon thereafter, however, the Court articulated a competing and in some respects inconsistent theory, which focused on the practice of democratic self-government. In this Essay, I examine each of these two theories of the First Amendment to illustrate the complex ways in which theory, doctrine, and common sense interact in First Amendment jurisprudence. My objective is to explore the sources of the current disarray of First Amendment doctrine and to assess the kinds of clarification that we may reasonably anticipate from an analytically rigorous First Amendment jurisprudence.

\section{LAYING THE GROUNDWORK: Justice Holmes' LaNDMARK OpINIONS}

Although First Amendment law did not spring into existence ex nihilo in the year 1919, ${ }^{2}$ First Amendinent jurisprudence as we now know it springs from a series of profoundly influential opinions by Oliver Wendell Holmes in the spring and fall of that year. The first of these opinions, Schenck $v$. United States, ${ }^{3}$ is the origin of the famous "clear and present danger" test.

The defendants in Schenck were charged with violating the Espionage Act of $1917^{4}$ by, among other things, "causing and attempting to cause insubordination ... in the military ... and to obstruct the recruiting and enlistment service of the United States, when the United States was at war with the German Empire." The defendants were prosecuted for circulating to draftees a leaflet opposing conscription; their defense was that the leaflet was "protected by the First Amendment to the Constitution.""

2. See David M. Rabban, Free SPeech in Its Forgotten Years 23 (1997) (tracing the origins of contemporary First Amendment doctrine).

3. 249 U.S. 47 (1919).

4. Espionage Act of June 15, 1917, ch. 30, § 3, 40 Stat. 217, 219 (repealed 1948).

5. Schenck, 249 U.S. at $48-49$.

6. Id. at 51 . 
Holmes' opinion for the Court firmly rejected this defense, but it did so without any discussion of the distinctive purposes or policies of the First Amendnient. Instead Holmes reasoned:

It seems to be admitted that if an actual obstruction of the recruiting service were proved, liability for words that produced that effect might be enforced.... If the act, (speaking, or circulating a paper,) its tendency and the intent with which it is done are the same, we perceive no ground for saying that success alone warrants making the act a crime.

Holmes argued that because obstruction of the draft constitutionally could be punished, so could the crime of attempted obstruction. He explained that when performed with the appropriate intent, the act of speaking or writing could constitute the crime of attempt if, as a matter of "proximity and degree," the "tendency" of the communication was to cause the punishable act of obstructing the draft. ${ }^{8}$ Holmes also added that, "[t]he question in every case is whether the words used are used in such circumstances and are of such a nature as to create a clear and present danger that they will bring about the substantive evils that Congress has a right to prevent." But the meaning of the novel phrase "clear and present danger" was obscure. It was clarified by Holmes' opinion for the Court in Debs $v$. United States, ${ }^{10}$ which held that speech merely had to have the "natural tendency and reasonably probable effect"11 of obstructing the recruiting service in order to constitute a punishable attempt to violate the Espionage Act of $1917 . .^{12}$

Holmes' logic in both Schenck and Debs remained entirely within the domain of substantive criminal law. Speech that was connected in a sufficiently close way to a crime was equivalent to an attempt to commit the crime. The closeness of the connection was to be assessed by doctrinal tests of "proximity and degree," tests rooted in the substantive law of attempt..$^{13}$ Although in some circumstances the First Amendment might

7. Id. at 52 .

8. Id.

9. Id.

10. 249 U.S. 211 (1919). Schenck was decided on March 3, 1919; Debs on March 10, 1919.

11. Id. at 216.

12. In Debs, the Court unanimously sustained the conviction of prominent socialist politician Eugene Debs for violating the Espionage Act of 1917 by attempting "to obstruct the recruiting and enlistment service of the United States." Id. at 212. The evidence of the crime consisted entirely of a non-inflammatory speech opposing World War I at a Socialists' convention. Holmes wrote:

[T] he jury were most carefully instructed that they could not find the defendant guilty for advocacy of any of his opimions unless the words used had as their natural tendency and reasonably probable effect to obstruct the recruiting service, \&c., and unless the defendant had the specific intent to do so in his mind. Id. at 216.

13. For good discussions of the relationship between the clear and present danger test and the substantive law of attempt, see Edward J. Bloustein, Criminal Attempts and the "Clear and Present 
safeguard speech-circumstances that Holmes did not explore-the Constitution did not protect speech so intimately bound up in action as to constitute the crime of attempt as defined by principles of the criminal law.

Eight months after Schenck, the Court was confronted with Abrams $v$. United States, ${ }^{14}$ a case that involved a prosecution under the Espionage Act of 1918. ${ }^{15}$ This Act was quite different from its 1917 predecessor. Tracking the words of the 1918 Act, the indictment at issue in Abrams charged the defendants with publishing:

[i]n the first count, "disloyal, scurrilous and abusive language about the form of Government of the United States;" in the second count, language "intended to bring the form of Government of the United States into contempt, scorn, contumely and disrepute;" and in the third count, language "intended to incite, provoke and encourage resistance to the United States in said war." The charge in the fourth count was that the defendants conspired "when the United States was at war with the Imperial German Government,... unlawfully and willfully, by utterance, writing, printing and publication, to urge, incite and advocate curtailment of production of things and products... necessary and essential to the prosecution of the war." 16

The defendants in Abrams raised strenuous constitutional objections to these charges. In his opinion for the Court, Justice Clarke disposed of these objections to their convictions by simple reference to Schenck. ${ }^{17}$ In fact, however, the prosecutions in Abrams posed entirely distinct First Amendment questions from those presented in Schenck, questions that would push Holmes fundamentally to revise the logic of his earlier opinions.

The Espionage Act of 1917 had prohibited action-obstructing the recruitment service of the United States during wartime. For this reason, Schenck was written to address the question of when speech could be characterized as a form of proscribed action. The Espionage Act of 1918, in contrast, prohibited language itself. In particular, counts one and two of the Abrams indictment, which essentially charged the common law crime of seditious libel, sought to punish speech for reasons that bore no relationship to action at all. The logic of Schenck was therefore quite irrelevant to these counts. It made no sense to ask whether language "intended to bring the form of Government of the United States ... into contempt" had the

Danger" Theory of the First Amendment, 74 CoRneLL L. REv. 1118 (1989); G. Edward White, Justice Holmes and the Modernization of Free Speech Jurisprudence: The Human Dimension, 80 CALIF. L. REv. 391 (1992).

14. 250 U.S. 616 (1919). The Court decided Abrams on November 10, 1919.

15. Espionage Act of May 16, 1918, ch. 75, 40 Stat. 553 (repcaled 1921).

16. Abrams, 250 U.S. at 617.

17. See id. at 619 . 
"natural tendency and reasonably probable effect" of causing some underlying evil that Congress had independently forbidden. The expression of such language was itself the evil that Congress wished to suppress.

Holmes immediately understood this difference. He realized that the Court was now forced, as it had not been forced in Schenck, to address the question of whether the First Amendment would permit the suppression of seditious libel. Holmes' answer was unequivocal: "I wholly. disagree with the argument of the Government that the First Amendment left the common law as to seditious libel in force." 18 This is the precise point in American constitutional history when First Amendment theory enters imto the construction of First Amendment doctrine, for Holmes' bold assertion required him to explain why the First Amendment prohibited the pumishment of seditious libel.

Seditious libel is a quintessentially political crime; its purpose is to protect the "special veneration ... due" to those who rule. ${ }^{19}$ Holmes could therefore have offered a theory of the First Amendment that derived from the particular characteristics of American democracy, from the fact that, as Madison put it, in our form of government "the censorial power is in the people over the Government, and not in the Government over the people." 20 But Holmes chose not to elaborate a political conception of the First Amendment. Instead, he proposed the now-famous theory of the marketplace of ideas:

But when men have realized that time has upset many fighting faiths, they may come to believe even more than they believe the very foundations of their own conduct that the ultimate good desired is better reached by free trade in ideas - that the best test of truth is the power of the thought to get itself accepted in the

18. Id. at 630 (Holmes, J., dissenting). This was a new position for Holmes. Twelve years before, he had written that the "main purpose" of the First Amendment was "to prevent all such previous restraints upon publications as had been practiced by other governments," and that the First Amendment cousequently did "not prevent the subsequent punishment of such as may be deemed contrary to the public welfare.... The preliminary freedom extends as well to the false as to the true; the subsequent punishment may extend as well to the true as to the false." Patterson v. Colorado, 205 U.S. 454,462 (1907) (citations omitted). There is some evidence that by the time of Schenck Holmes was beginning to rethink this position. For example, he wrote in Schenck:

It well may be that the prohibition of laws abridging the freedom of speech is not confined to previous restraints, although to prevent them may have been the main purpose, as intimated in Patterson v. Colorado. We admit that in many places and in ordinary times the defendants in saying all that was said in the circular would have been within their constitutional rights. Schenck, 249 U.S. at 51-52 (citation omitted). For a recent discussion of Holmes' famous change of mind, see Bradley C. Bobertz, The Brandeis Gambit: The Making of America's "First Freedom," 1909-1931, 40 WMI. \& MARY L. Rev. 557, 587-607 (1999).

19. Francis Ludlow Holt, The LaW of Libel 90 (1816). For a good explication, see 2 James Fitzjames Stephens, A History of the Criminal Law of England 299-300 (1883).

20. 4 ANnals of Congress 934 (1794). This is the logic that the Court adopted almost 50 years later when it finally ruled that the First Amendment did indeed forbid the punishment of seditious libel. See New York Times Co. v. Sullivan, 376 U.S. 254, 275 (1964). 
competition of the market, and that truth is the only ground upon which their wishes safely can be carried out. That at any rate is the theory of our Constitution. It is an experiment, as all life is an experiment. ... While that experiment is part of our system I think that we should be eternally vigilant against attempts to check the expression of opinions that we loathe and believe to be fraught with death, unless they so imminently threaten immediate interference with the lawful and pressing purposes of the law that an immediate check is required to save the country. ${ }^{21}$

Holmes' Abrams dissent is sometimes interpreted as representing an economic view of freedom of speech, as though the metaphors of "free trade in ideas" and "the competition of the market" meant that the constitutional value of freedom of speech literally entailed the maximization of consumer preferences. ${ }^{22}$ But in Abrams Holmes explicitly oriented his theory of the First Amendment toward the value of truth, which he linked to the concept of "experiment." This strongly suggests that the Abrams dissent is best understood as an expression of American pragmatic epistemology, with which Holnues was very familiar. ${ }^{23}$ Pragmatists like William James were prone to using economic metaphors to capture the idea that truth must be experinientally determined from the properties of experience itself. ${ }^{24}$ One could understand Holmes, then, as claiming that the property of experience relevant to the determination of the truth of political opinion is that democratic citizens come to believe in an idea and to act on it.

The difficulty with this interpretation, however, is that Holmes phrased his argument in terms of an account of truth generally, rather than of specifically political truth. In the spirit of the liberal philosophical position of John Stuart Mill, ${ }^{25}$ Holmes proposed a theory of the First Amendment addressed to the abstract requirements of freedom of thought. As Holmes would write in a subsequent dissent: "[I]f there is any principle of the Constitution that more imperatively calls for attachment than any other it is the principle of free thought-not free thought for those who agree with us but freedom for the thought that we hate." 26

21. Abrams, 250 U.S. at 630 (Holmes, J., dissenting).

22. Cass R. Sunstein, One Case at a Time: Judicial Minimalism on the Supreme Court $172-76$ (1999).

23. See Thomas C. Grey, Holmes and Legal Pragmatism, 41 STAN. L. Rev. 787, 788 (1989).

24. Thus James wrote: "Pragmatism ... asks its usual question. 'Grant an idea or belief to be true,' it says, 'what concrete difference will its being true make in any one's actual life? ... What experiences will be different from those which would obtain if the belief wcre false? What, in short, is the truth's cash-value in experiential terms?"' William James, Pragmatism: A New Name for Some OLD WAYS OF THINKING 200 (1908).

25. See John Stuart Mill, ON LiberTy (Elizabeth Rapaport ed., Hackett Publishing Co. 1978) (1859).

26. United States v. Schwimmer, 279 U.S. 644, 654-55 (1929) (Holmes, J., dissenting). 
Holmes' dissent in Abrams contains the first judicial expression of a theory of the First Amendment, and the theory had immediate and powerful doctrinal consequences. Counts three and four of the Abrams indictment alleged the publication of language directed to producing certain actions-resisting the United States' prosecution of the war and curtailing the production of necessary war niaterial. It was clear that these actions could be made criminal, and Holmes' earlier opinions in Schenck and Debs had explicitly held that language having the tendency to produce crimes and spoken with the specific intent to produce crinies could be punished as attempts to commit crimes. One could characterize the Espionage Act of 1918 as a legislative judgment that speech advocating or encouraging prohibitable actions would have the tendency to produce those actions. Given the generous and elastic breadth of the "bad tendency" test Holmes had himself articulated and applied in Debs, this legislative judgnent was no doubt reasonable. ${ }^{27}$ It was thus only a small step for the Court to hold that this language could constitutionally be punished under Schenck and Debs.

Counts three and four of the Abrams indictment thus directly forced Holmes to evaluate the relationship between his new theory of the First Amendnient and the doctrinal test he had himself previously announced. Holmes immediately realized that if speech could be suppressed merely because it tended to produce prohibited action, the marketplace of ideas could easily be savaged by state regulation. ${ }^{28}$ In an admirable effort to reshape First Amendment doctrine to iniplement the purposes of First Amendinent theory, therefore, Holmes fundamentally transformed the bad tendency test of Debs and Schenck. He reinterpreted the "clear and present danger" requirement to require a showing of imminence. Holmes argued in Abrams that even if speech could be characterized by substantive criminal

27. In fact in 1925 Justice Sanford cleverly traded on this logic to uphold the criminal anarchy statute of New York. See Gitlow v. New York, 268 U.S. 652 (1925). Like the Espionage Act of 1918, the New York criminal anarchy statute prohibited language that was connected to certain harms. In the case of the New York statute, the harms were those of violent revolution. Sanford reasoned that the statute constituted a legislative "determination" that speech advocating violent revolution posed "a sufficient danger of substantive evil" to be regulated, and he shrewdly argued that, as Holmes and Brandeis had contended in other cases, legislative judgments in such matters ought be "given great weight." Id. at 668-70. Sanford observed that such legislative judgments posed an "entirely different" question "from that involved in those cases where the statute merely prohibits certain acts involving the danger of substantive evil, without any reference to language itself, and it is sought to apply its provisions to language used by the defendant for the purpose of bringing about the prohibited results." Id. at 670-71. In the latter case, Sanford conceded, courts must independently determine whether a defendant's language "involved such likelihood of bringing about the substantive evil as to deprive it of the constitutional protection." Id. at 671 . But, he concluded, the test of "natural tendency and probable effect" set forth in Schenck and Debs "has no application... where the legislative body itself has previously determined the danger of substantive evil arising from utterances of a specified character." Id.

28. As Holmes remarked: "Congress certainly cannot forbid all effort to change the mind of the country." Abrams, 250 U.S. at 628 (Holmes, J., dissenting). 
law as an "attempt," the First Amendment should nevertheless prohibit its punishment unless there were an "emergency," unless "the expression of opinions ... so imminently threaten immediate interference with the lawful and pressing purposes of the law that an immediate check is required to save the country."29

By tightening the constitutionally required connection between speech and action in this way, Holmes sought both to provide ample room for the functioning of the marketplace of ideas and to empower the state to regulate speech when it was sufficiently close to causing prohibitable substantive evils. Demonstrating the seriousness of his new test, Holmes concluded that the Abrams defendants could not constitutionally be convicted because "nobody can suppose that the surreptitious publishing of a silly leaflet by an unknown man, without more, would present any immediate danger that its opinions would hinder the success of the government arms ...."30

The path of Holmes' development fron Schenck to Abrams exemplifies the dialectical relationship between First Amendment doctrine and First Amendment theory. As he refined his understanding of the purposes of the First Amendment, Holmes was forced to revise and reshape the doctrinal tests he had himself announced only months before. This is because Holmes fully appreciated that the purpose of doctrine is to institutionalize constitutional objectives. A corollary of this insight, however, is that First Amendment doctrine will suffer if it is expected to serve conflicting or inconsistent objectives.

The potential for this problem materialized shortly after Holmes' Abrams dissent. In one of its very first decisions striking down a state regulation of speech, the Court in 1931 articulated a specifically political account of the First Amendment that was quite distinct from the marketplace of ideas. "The maintenance of the opportunity for free political discussion to the end that government may be responsive to the will of the people and that changes may be obtained by lawful means," the Court said, "is a fundamental principle of our constitutional system." 31

The democratic theory of the First Amendment differs in important respects from the marketplace of ideas theory, most notably because the former protects speech insofar as it is required by the practice of selfgovernment, while the latter protects speech insofar as it is required to facilitate the pursuit of truth. To the extent that the practice of selfgovernment serves ends distinct fron and potentially inconsistent with the pursuit of truth, and to the extent that the pursuit of truth entails practices inconsistent with self-government, these two theories diverge. Both

29. Id. at 630 .

30. Id. at 628 .

31. Stromberg v. California, 283 U.S. 359, 369 (1931). 
theories have nevertheless remained influential in the Court's thinking. The Court can announce both that " ' $\mathrm{i}] \mathrm{t}$ is the purpose of the First Amendment to preserve an uninhibited marketplace of ideas in which truth will ultimately prevail," ${ }^{\prime 32}$ and that the objective of the First Amendment is to function as the "guardian of our democracy. ${ }^{133}$ Almost from its inception, First Amendment doctrine has been caught in the crossfire between these two theories of freedom of speech.

To explore this contested terrain, we need to have some concrete idea of the practical differences between these two distinct perspectives. The next Part of this Essay evaluates the theory of the marketplace of ideas, with particular attention to the tension between its doctrinal development and the actual shape of our First Amendment tradition. Part III discusses the ambiguities and implications of the democratic theory, while the fourth and final Part compares the doctrinal implications of the two theories and attempts to draw some general conclusions about the relationship between First Amendment theory and doctrine.

III

\section{The FIRST AMENDMENT AND THE MARKETPLACE of IDEAS}

The theory of the marketplace of ideas focuses on "the truth-seeking function" 34 of the First Amendment. It extends the shelter of constitutional protection to speech so that we can better understand the world in which we live. It would follow from the theory, therefore, that at a minimum the Constitution ought to be concerned with all communication conveying ideas relevant to our understanding the world, whether or not these ideas are political in nature. This does not mean, of course, that the Constitution would prohibit all regulation of such communication. But it does imply that regulation of such communication ought to be evaluated according to the constitutional standards of the theory.

This is in fact the way that contemporary First Amendment doctrine defines the range of communication that triggers First Amendment scrutiny. The so-called Spence test, for example, holds that the First Amendment will come "into play" whenever " an intent to convey a particularized message [is] present," and, given the context, "the likelihood [is] great that the message would be understood by those who viewed it." "'35 This broad doctrinal rule uses the potential communication of ideas to define what will count as "speech" for purposes of the First

32. Turner Broad. Sys., Inc. v. FCC, 507 U.S. 1301, 1304 (1993) (quoting Red Lion Broad. Co. v. FCC, 395 U.S. 367, 390 (1969)); see also McIntyre v. Ohio Elections Comm'n, 514 U.S. 334, 341 (1995); Hustler Magazine, Inc. v. Falwell, 485 U.S. 46, 52, 56 (1988).

33. Brown v. Hartlage, 456 U.S. 45, 60 (1982).

34. Hustler Magazine, 485 U.S. at 52.

35. Texas v. Johnson, 491 U.S. 397, $403-04$ (1989) (quoting Spence v. Washington, 418 U.S. 405, 410-11 (1974)). 
Amendment. It thus crisply expresses the principle that the regulation of any communication capable of increasing understanding must be subjected to constitutional review.

While this principle follows more or less directly from the theory of the marketplace of ideas, it does not in fact correspond to the common sense of judges, as expressed in the resolution of actual cases. Much behavior that passes the Spence test because it successfully communicates a particularized message is not regarded as bringing the First Amendment into play. Such conduct ranges from terrorist bombings to written warnings on consumer products. ${ }^{36}$ It is not that regulation of this conduct is affirmatively permitted by the First Amendment; it is rather that courts do not even subject such regulation to First Amendment scrutiny. When measured by the actual shape of the law, therefore, it is immediately apparent that the Spence test, which defines speech in a manner that follows from the theory of the marketplace of ideas, simply cannot stand. ${ }^{37}$

First Amendment jurisprudence is filled with analogous disparities between actual decisions and doctrinal rules that would appear to follow from the theory of the marketplace of ideas. For example, it is black-letter law that the First Amendment applies "the most exacting scrutiny to regulations that suppress, disadvantage, or impose differential burdens upon speech because of its content." ${ }^{\text {"S }}$ Such a rule would seem to express the requirement that the state remain neutral within the marketplace of ideas, for it is formulated in such a way as to apply not merely to political speech, but to the entire range of "speech" as defined by the Spence test. Yet content-based regulation of speech is routinely enforced without special constitutional scrutiny, as for example when lawyers or doctors are held liable in professional malpractice for the communication of irresponsible opinions. ${ }^{39}$ Or consider the black-letter rule that "[t]he First Amendment recogmizes no such thing as a 'false' idea." 40 This rule also seems to express a central value of the marketplace of ideas, and it is accordingly also said to apply generally to "speech," and not merely to political speech. Yet "false" ideas can be regulated not only in the context of professional malpractice, but also in the context of commercial speech, where speakers can be sanctioned if they communicate in ways that are "misleading." 41

36. For a typical consumer product warning case, see Hahn v. Sterling Drug, Inc., 805 F.2d 1480 (11th Cir. 1986).

37. For a full discussion of the inadequacy of the Spence test, see Robert Post, Recuperating First Amendment Doctrine, 47 STAN. L. REv. 1249, 1250-60 (1995).

38. Turner Broad. Sys., Inc. v. FCC, 512 U.S. 622, 642 (1994).

39. See, e.g., Togstad v. Vesely, Otto, Miller \& Keefe, 291 N.W.2d 686 (Minn. 1980); Carson v. City of Beloit, 145 N.W.2d 112 (Wis. 1966).

40. Hustler Magazine, 485 U.S. at 51.

41. See, e.g., Rubin v. Coors Brewing Co., 514 U.S. 476, 482 (1995). 
There is thus a disturbingly large gap between the actual shape of our constitutional law and doctrinal rules that seem to express the theory of the marketplace of ideas. This gap suggests either that we do not believe in the theory of the marketplace of ideas, or that our doctrine has somehow misconstrued the actual implications of the theory. The latter alternative seems to me the more plausible. Although First Amendment doctrine presently understands "the truth-seeking function" of the marketplace of ideas to flow directly froin the communicative properties of speech, in fact "truth-seeking" requires much more. It requires an important set of shared social practices: the capacity to listen and to engage in self-evaluation, as well as a commitment to the conventions of reason, which in turn entail aspirations toward objectivity, disinterest, civility, and mutual respect. Thus John Dewey once remarked that rational deliberation depends upon "the possibility of conducting disputes, controversies and conflicts as cooperative undertakings in which both parties learn by giving the other a chance to express itself," and that this cooperation is inconsistent with one party conquering another "by forceful suppression ... a suppression which is none the less one of violence when it takes place by psychological means of ridicule, abuse, intimidation, instead of by overt imprisonment or in concentration camps." ${ }^{\prime 2}$

The social practices necessary for a marketplace of ideas to serve a "truth-seeking function" are perhaps most explicitly embodied in the culture of scholarship inculcated in universities and professional academic disciplines. Certainly this culture is what Charles Peirce had in mind when he advocated "the method of science" as a preferred avenue toward truth, a method that he explicitly contrasted with the "method of authority" which employs the "orgamized force" of the state to suppress "liberty of speech."43 In this limited sense there is deep insight in the Court's often repeated observation that " $[\mathrm{t}]$ he college classroom with its surrounding environs is peculiarly the "marketplace of ideas." "44 The augmentation of knowledge within professional academic disciplines does not flow merely froin the fact that ideas are formally free from official censorship, but rather from the fact that this freedom is embedded within what John Stuart Mill once

42. John Dewey, Creative Democracy-The Task Before Us, reprinted in CLASSIC AMERICAN Philosophers 389, 393 (Max H. Fisch ed., 1951).

43. Charles S. Peirce, The Fixation of Belief, in Values in a UNiverse of Chance 91, 11011 (Philip P. Wiener ed., 1958). It is likely that Holmes was exposed to this essay while he was a member of the Metaphysical Club. See David S. Bogen, The Free Speech Metamorphosis of Mr. Justice Holmes, 11 HofstRa L. Rev. 97, 120 (1982).

44. Healy v. James, 408 U.S. 169, 180 (1972); see, e.g., Widmar v. Vincent, 454 U.S. 263, 267 n.5 (1981); Tinker v. Des Moines Indep. Community Sch. Dist., 393 U.S. 503, 512 (1969). In another sense, however, the Court's observation is fundamentally inaccurate, for the classroom itself represents a managerial domain dedicated to instruction, rather than to the open-ended pursuit of knowledge. See Robert C. Post, Racist Speech, Democracy, and the First Amendment, 32 WM. \& MARy. L. Rev. 267, 317-25 (1990). The marketplace of ideas most exactly applies to the enterprise of scholarship itself. 
called a "real morality of public discussion." ${ }^{45}$ In the absence of such a morality, it is merely tautological to presume that truth is what most people come to believe after open discussion. ${ }^{46}$

It is thus inaccurate to infer that the theory of the marketplace of ideas requires that the First Amendment protect all speech that communicates ideas. Instead the theory requires the protection only of speech that communicates ideas and that is embedded in the kinds of social practices that produce truth. ${ }^{47}$ The Court's failure to offer doctrinal articulation of the social prerequisites of truth-seeking is a significant source of the gap between doctrinal rules attempting to embody the theory of the marketplace of ideas and the actual shape of our First Amendment law.

Society consists of myriad forms of social practices, and speech is constitutive of almost all of these practices. The number of these practices that can plausibly be rendered consistent with the "truth-seeking function" of a marketplace of ideas is relatively small. It makes no sense, for example, to locate a "truth-seeking function" in the speech between lawyers or doctors and their clients, or in the communication contained in product warning labels. Judges recognize this distinction; their common sense rebels against applying to such situations doctrinal rules based upon completely incompatible social presuppositions. That is why First Amendment doctrine differs from the actual shape of our law.

To implement accurately the theory of the marketplace of ideas, therefore, doctrinal rules would have to confine the scope of their application to those domains of social life where the prerequisite forms of social organization for a functioning marketplace of ideas either were present or could constitutionally be conjured into existence. Exactly where the theory could appropriately be applied, of course, would be highly debatable, but I suspect that under any fair construction the scope of its application would be quite narrow.

\section{III}

\section{The First Amendment and Democratic SelF-Government}

If the theory of the marketplace of ideas tends to efface the social practices by which it is in fact sustained, thereby inducing a free-floating image of pure communication, the democratic theory has not suffered any such liability. It has never been subject to the same mystification as has the marketplace of ideas. We instantly recognize self-government as a discrete

45. MrLL, supra note 25, at 52.

46. See Frederick Schauer, Free Speech: A Philosophical Enquiry 20 (1982).

47. I have argued elsewhere that any function attributed to the First Amendment will require a form of social organization in order to accomplish its ends, and that the Court's tendency to formulate rules applicable to speech itself, independent of social organization, has for this rcason been a major source of doctrinal confusion within First Amendment law. See Post, supra note 37. 
and embodied social practice, and for this reason courts applying democratic theory have been clear that the First Amendment protects only speech pertiment to self-determination. Thus, for example, in the important early decision of Thornhill v. Alabama ${ }^{48}$ the Court asserted that because freedom of speech was essential to "the maintenance of democratic institutions," it embraced "the liberty to discuss publicly and truthfully all matters of public concern" so that "members of society" could "cope with the exigencies of their period." $" 49$

Democratic theory, however, has been subject to its own ambiguities. The constitutional meaning of self-government has proved intensely controversial. It is, of course, generally agreed that democracy subsists in the people governing themselves, but historically there have been two competing accounts of the practice of self-determination, each with different implications for First Amendment doctrine.

One account, associated with the work of Alexander Meiklejohn, views democracy as a process of "the voting of wise decisions." ${ }^{\circ 0}$ The First Amendment is understood to protect the communicative processes necessary to disseminate the information and ideas required for citizens to vote in a fully informed and intelligent way. Meiklejohn analogizes democracy to a town meeting; the state is imagined as a moderator, regulating and abridging speech "as the doing of the business under actual conditions may require." ${ }^{51}$ For this reason, "abusive" speech, or speech otherwise inconsistent with "responsible and regulated discussion," can and should be suppressed. ${ }^{52}$ From the Meiklejohnian perspective, "the point of ultimate interest is not the words of the speakers, but the minds of the hearers," ${ }^{, 53}$ so that the First Amendment is seen as safeguarding collective processes of decision making rather than individual rights. Meiklejohn summarizes this assumption in a much quoted and influential aphorism: "What is essential is not that everyone shall speak, but that everything worth saymg shall be said." 54

The alternative account of democracy, which I shall call the "participatory" theory, does not locate self-governance in mechanisms of decision making, but rather im the processes through which citizens come to identify a government as their own. ${ }^{55}$ According to this theory,

\footnotetext{
48. 310 U.S. $88(1940)$.

49. Id. at $96,101-02$.

50. Alexander Meiklejohn, Political Freedom: The Constitutional Powers of the PEOPLE 26 (1965). For a full discussion and critique, see Robert Post, Meiklejohn's Mistake: Individual Autonomy and the Reform of Public Discourse, 64 U. CoLo. L. Rev. 1109 (1993).

51. MEIKLEJOHN, supra note 50 , at 24 .

52. Id. at 25 .

53. Id. at 26.

54. Id.

55. For a discussion of the contrast, see Post, supra note 50; see also Robert Post, Equality and Autonomy in First Amendment Jurisprudence, 95 MICH. L. REv. 1517, 1523 (1997).
} 
democracy requires that citizens experience their state as an example of authentic self-determination. How such an experience can be sustained presents something of a puzzle, because citizens can expect to disagree with many of the specific actions of their government. The solution to this puzzle must be that citizens in a democracy experience their authorship of the state in ways that are anterior to the making of particular decisions. The participatory account postulates that it is a necessary precondition for this experience that a state be structured so as to subordinate its actions to public opinion, and that a state be constitutionally prohibited from preventing its citizens from participating in the communicative processes relevant to the formation of democratic public opinion. ${ }^{56}$

If, following the usage of the Court, we term these communicative processes "public discourse, function of the First Amendment to be the safeguarding of public discourse from regulations that are inconsistent with democratic legitimacy. State restrictions on public discourse can be inconsistent with democratic legitimacy in two distinct ways. To the extent that the state cuts off particular citizens from participation in public discourse, it pro tanto negates its claim to democratic legitimacy with respect to such citizens. To the extent that the state regulates public discourse so as to reflect the values and priorities of some vision of collective identity, it preempts the very democratic process by which collective identity is to be determined.

Although both the Meiklejohnian and participatory perspectives share the common problem of specifying which communication is necessary for self-government and hence worthy of constitutional protection, they differ in at least two fundamental respects. First, the Meiklejohnian approach interprets the First Amendment primarily as a shield against the "mutilation of the thinking process of the community," whereas the participatory approach understands the First Amendment instead as safeguarding the ability of individual citizens to participate in the formation of public opinion. The Meiklejohnian theory thus stresses the quality of public debate, whereas the participatory perspective emphasizes the autonomy of individual citizens.

Second, the Meiklejohnian perspective imagines the state within the arena of public discourse as occupying the position of a neutral moderator, capable of saving public discourse from "mutilation" by distinguishing between relevant and irrelevant speech, abusive and non-abusive speech, high and low value speech, and so forth. It specifically repudiates the

56. For a fully developed explanation of this view, see ROBERT C. POST, Constitutional Domains 179-96 (1995).

57. Rosenberger v. University of Virginia, 515 U.S. 819, 831 (1995); see also Hustler Magazine, Inc. v. Falwell, 485 U.S. 46, 55 (1988).

58. MEIKLEJOHN, supra note 50, at 27 (emphasis deleted). 
notion that public discourse is "a Hyde Park," filled with "unregulated talkativeness." 59 The participatory approach, in contrast, denies that there can be any possible neutral position within public discourse, ${ }^{60}$ because public discourse is precisely the site of political contention about the nature of collective identity, and it is only by reference to some vision of collective identity that speech can be categorized as relevant or irrelevant, abusive or not abusive, high or low value. The participatory theory understands national identity to be endlessly controversial, so that national identity cannot without contradiction provide grounds for the censorship of public discourse itself.

In both of these respects, the Meiklejohnian perspective is structurally quite analogous to the theory of the marketplace of ideas. Both theories focus primarily on inaintaining the integrity of processes of collective thinking. The Meiklejohnian approach seeks to safeguard the dialogue necessary for voting wisely; the theory of the marketplace of ideas seeks to protect the dialogue necessary for advancing truth. Just as Holmes in his Abrams dissent stressed that in proposing the theory of the marketplace of ideas he was "speaking only of expressions of opimion and exhortations," "between cognitive and noncognitive aspects of speech" and to award "less constitutional protection" to the latter.$^{62}$ Both theories are keenly aware of the prerequisites for constructive thinking. Just as Dewey viewed "ridicule, abuse, [and] intimidation" as incoinpatible with rational discussion, ${ }^{63}$ so Meiklejohn viewed "abusive" speech as incoinpatible with a well-ordered town meeting.

\section{IV}

\section{ReCONCILING First Amendment THEORY AND DOCTRINe}

It is therefore particularly significant that our First Amendment tradition decisively rejects these critical components of both the Meiklejohnian perspective and the theory of the marketplace of ideas. American courts have consistently opted to protect individual autonoiny against regulations of public discourse designed to inaintain the integrity of collective thinking processes. In the area of campaign finance reform, for example, the Supreme Court has forcefully asserted that "the concept that government may restrict the speech of some elements of our society in order to enhance the relative voice of others" should be repudiated as "wholly foreign to the

59. Id. at 25-26.

60. As Kenneth Karst once famously remarked, "The state lacks 'moderators' who can be trusted to know when 'everything worth saying' has been said." Kenneth Karst, Equality as a Central Principle in the First Amendment, 43 U. CHI. L. Rev. 20, 40 (1975).

61. 250 U.S. at 631.

62. Cass R. Sunstein, Pomography and the First Amendment, 1986 DuKE L.J. 589, 603.

63. Dewey, supra note 42 , at 393 ; see also text accompany note 42 . 
First Amendment." ${ }^{64}$ In contexts ranging from restrictions on pornography and hate speech to "right-of-reply" statutes applicable to newspapers, contemporary advocates of the Meiklejohnian position have sharply and continuously complained of the tendency of courts to extend constitutional protection to individual rights even when the exercise of such rights "distorts" public discussion by perpetuating imbalances of social and economic power. ${ }^{65}$

This commitment to individual rights is one of the hallmarks of our distinctively American free-speech jurisprudence. The one notable exception to this commitment has been the Court's approval of federal regulations of the broadcast media. These regulations, which were designed to promote a balanced and well-ordered national dialogue on public issues, were clearly inspired by Meiklejohmian principles. Before adjudging such regulations constitutional, however, the Supreme Court took extraordinary care to characterize broadcast licensees as trustees for the speech of others, rather than as themselves direct participants in the conduct of selfgovernance. ${ }^{66}$ This characterization enabled the Court to regard the imposition of broadcast regulations as not improperly restricting autonomous participants in the process of self-determination, and hence as compatible with the participatory approach.

American free-speech jurisprudence is also unique in its refusal to permit state restrictions within public discourse of irrational or abusive speech, or speech otherwise deemed incompatible with rational dialogue. Beginning with cases like Cantwell v. Connecticut $t^{67}$ and Terminiello $v$. Chicago, ${ }^{68}$ First Amendment decisions have stood foursquare for the proposition that constitutional protection should be extended to speech within public discourse that is "outrageous"69 or "offensive",70 that is filled with "exaggeration" or "vilification;" that is "indecent",72 that ruptures the "dignity" of its recipient; ${ }^{.3}$ or that is perceived as an instrument of "aggression and personal assault." 74 According to both the Meiklejohnian tradition and the theory of the marketplace of ideas, there is

64. Buckley v. Valeo, 424 U.S. 1, 48-49 (1976).

65. See, e.g., OWEN M. Fiss, Liberalism Divided: FreEdom of SPEECH ANd THE MANy UsES OF STATE POWER (1996).

66. See Red Lion Broad. Co. v. FCC, 395 U.S. 367, 389-90 (1969). Over time, this characterization of broadcast media has proved historically unstable. For a discussion, see Robert $\mathrm{C}$. Post, Subsidized Speech, 106 YALE L.J. 151, 158-60 (1996).

67. 310 U.S. 296 (1940).

68. 337 U.S. 1 (1949).

69. Hustler Magazine, Inc. v. Falwell, 485 U.S. 46, 53 (1988).

70. Cohen v. California, 403 U.S. 15, 22 (1971).

71. Cantwell v. Connecticut, 310 U.S. 296, 310 (1940).

72. Reno v. ACLU, 521 U.S. 844, 869 (1997).

73. Boos v. Barry, 485 U.S. 312,322 (1988).

74. Time, Inc. v. Hill, 385 U.S. 374, 412 (1967) (Fortas, J., dissenting). 
little constitutional reason to protect such speech, because it runs so directly contrary to the prerequisites of constructive thinking.

The participatory approach, by contrast, explains both why such speech is protected and why this protection is limited. The participatory approach does not focus on the cognitive cogency of speech, but rather on its facilitation of democratic participation. Even irrational and abusive speech can, within particular circunistances, serve as a vehicle for the construction of democratic legitimacy. When irrational and abusive speech serves this function, which is to say when it is deemed within public discourse ${ }^{75}$ its regulation would both compromise the neutrality of the state and the autonomy of those participating within public discourse. But when such speech does not serve this function, which is to say when it is deemed not within public discourse, it can be and commonly is regulated. ${ }^{76}$ The upshot is a uniquely American jurisprudence that displays an overriding constitutional conviction to interpret the First Amendment "to ensure that the individual citizen can effectively participate in and contribute to our republican systein of self-government."77

This analysis suggests that where the doctrinal implications of different prominent theories of the First Amendment collide, courts will tend to give priority to the participatory theory of democracy. But this does not mean that other theories do not continue to have weight and consequence when they are not inconsistent with the participatory theory. Just as the niarketplace of ideas continues to imform constitutional understandings of academic freedom, so the Meiklejohnian perspective continues to structure the regulation of speakers like the broadcast media, who are not understood to be participants in public discourse.

The full force of the participatory theory is most strikingly revealed when its requirenients are contrasted with a regime of speech governed by a coinpeting theory, like the Meiklejohnian approach. Consider, for exan1ple, the area of "commercial speech." The Court has never intimated that commercial speech should receive constitutional protection because participation in such speech facilitates democratic legitimacy. Instead the Court has explained that commercial speech inerits First Aunendment

75. The boundaries of public discourse are fixed by reference to various factors, including the content of speech (whether it is about a "public figure" or a matter of "public concern") and the method of the speech's distribution (whether it was disseminated to the public at large through a "medium for the communication of ideas"). For a discussion of the nature of these boundaries, see Robert C. Post, The Constitutional Concept of Public Discourse: Outrageous Opinion, Democratic Deliberation, and Hustler Magazine v. Falwell, 103 HaRv. L. REv. 601, 667-84 (1990). For a discussion of the concept of a "medium for the communication of ideas," see Post, supra note 37.

76. For examples of such regulation, see Florida Bar v. Went For It, Inc., 515 U.S. 618, 624 (1995); Bethel Sch. Dist. No. 403 v. Fraser, 478 U.S. 675, 677-79 (1986); Ohralik v. Ohio State Bar Ass'n, 436 U.S. 447, 461 (1978); Contreras v. Crown Zellerbach Corp., 565 P.2d 1173 (Wash. 1977).

77. Globe Newspaper Co. v. Superior Court, 457 U.S. 596, 604 (1982). 
concern because it serves an "informational function." "[T] "T]he free flow of commercial information," the Court has argued, is "indispensable to the formation of intelligent opinions" necessary for enlightened "public decisionmaking in a democracy." 79

This reasoning represents a classic explication of the Meiklejohnian tradition. It stresses the cognitive contribution of speech to democratic decision making, rather than the legitimation-producing effects of speech understood as a vehicle of participation. The pattern of constitutional protection that the Court has extended to commercial speech thus follows a distinctly different pattern than that afforded to public discourse. The Court has allowed regulations of commercial speech that are necessary to preserve the integrity of its informational function, and hence it has accorded to commercial speech a "lesser protection." ${ }^{180}$ Commercial speech can be suppressed if it is "misleading"81 or "overreaching" 82 or "intrusive" and invasive of "privacy." ${ }^{83}$ Yet because commercial speech is not understood as a vehicle for participation in the creation of democratic legitimacy, such regulation is not inconsistent with the participatory approach.

The example of commercial speech suggests that First Amendment jurisprudence contains several operational and legitimate theories of freedom of speech, so that it is quite implausible to aspire to clarify First Amendment doctrine by abandoning all but one of these theories. In this short Essay, I have been able to discuss only the most important theories of the First Amendment, but there are certainly others. Many prominent acadeinics, for example, have argued that the First Amendment should be interpreted so as to protect a value known variously as "individual selfrealization," "individual self-fulfillment," ${ }^{185}$ or "human liberty," occasionally there have been court decisions that seem to be inexplicable except by reference to some such theory of "individual liberty." ${ }^{177}$ But there are not many such decisions, and so the theory does not seem to be very powerful.

Sometimes diverse First Amendment theories converge on similar doctrinal rules. The "clear and present danger test" formulated by Holmes

78. Central Hudson Gas \& Elec. v. Public Serv. Comm'n, 447 U.S. 557, 563 (1980).

79. Virginia State Bd. of Pharmacy v. Virginia Citizens Consumer Council, 425 U.S. 748, 765

(1976).

80. United States v. Edge Broad. Co., 509 U.S. 418, 426 (1993).

81. Central Hudson, 447 U.S. at 566.

82. Ohralik v. Ohio State Bar Ass'n, 436 U.S. 447, 461 (1978).

83. Florida Bar v. Went For It, Inc., 515 U.S. 618, 624 (1995).

84. Martin H. Redish, The Value of Free Speech, 130 U. PA. L. REv. 591,593 (1982).

85. ThOMAS I. EMERSON, THE SYSTEM OF FREEDOM OF EXPRESSION 6 (1970).

86. C. Edwin BaKer, Human Liberty aNd Freedom of SPEech (1989).

87. See, e.g., Stanley v. Georgia, 394 U.S. 557, 565 (1969). For a useful reccnt study of the state of scholarship on this theory of the First Amendment, see Brian C. Murchison, Speech and the SelfRealization Value, 33 HARv. C.R.-C.L. L. REv. 443 (1998). 
may well be an example of such an over-determined rule. But sometimes diverse First Amendment theories will require inconsistent doctrinal regimes, and when this occurs, courts must decide which theory is to be given priority. I have argued in this Essay that on the whole courts tend to give priority to the participatory theory of democracy, so that courts will not implement the doctrinal implications of other theories when they are inconsistent with the participatory approach.

The example of commercial speech, however, indicates that courts will nevertheless feel free to impose the doctrinal implications of other theories of the First Amendment when they are not inconsistent with the requirements of the participatory theory. We might generalize this insight by observing that theories of the First Amendment can be arranged according to a "lexical priority." When theories conflict with each other, courts must decide the order im which theories should take precedence. To say, therefore, that a theory like "individual self-fulfillment" or even the marketplace of ideas, is not powerful, is to say that it ranks low in this lexical order, and that it cannot explain many decisions whose outcomes are not also required by lexically prior theories.

This way of conceptualizing the relationship of doctrine to theory accepts that we shall always have inconsistent regimes of First Amendment doctrine. But it also promises that this inconsistency can itself display a certain kind of order. The rules of the participatory theory will be imposed when required by that theory; the rules of the Meiklejohmian perspective will be imposed when required by that perspective and not incompatible with the participatory theory; the rules of the theory of the marketplace of ideas will be imposed when required by that theory and not incompatible with the participatory and Meiklejohnian approaches; and so forth.

The nature of this lexical ordering has been obscured by the tendency of courts to speak of First Amendment rules as applying to speech generally, thus systematically effacing the domains of speech actually implicated by different First Amendment theories. For example, in describing the First Amendment regime miposed upon commercial speech, the Supreme Court will remark that "[o]ur jurisprudence has emphasized that 'commercial speech [enjoys] a limited measure of protection, commensurate with its subordinate position in the scale of First Amendment values,' and is subject to 'modes of regulation that might be impermissible in the realm of noncommercial expression." "88 By characterizing commercial speech as subordinate to "noncommercial expression," the Court propagates a patent falsehood. There are many areas of noncommercial expression that receive no First Amendment protection at all, as the example of consumer product warnings illustrates. Thus the Court should instead have said that

88. Board of Trustees v. Fox, 492 U.S. 469, 477 (1989) (quoting Ohralik v. Ohio State Bar Ass'n, 436 U.S. 447, 456 (1978)). 
commercial speech receives less protection than "public discourse," thereby making clear that what is really at stake is the priority between the participatory and the Meiklejohnian theories of the First Amendment.

\section{CONCLUSION}

By perennially speaking as though speech were itself the object of First Amendment doctrine, the Court has promulgated a confusing regime of conflicting doctrinal rules that cannot possibly mean what they say. This is the underlying cause of what is now generally acknowledged to be the sorry state of First Amendment doctrine. ${ }^{89}$ If, as I have suggested, the plurality of legitimate First Amendment theories limits the kind of doctrinal simplicity and clarity that is constitutionally obtainable, we can nevertheless expect courts to specify the lexical priority among First Amendment theories, as well as to be clear about the domain of speech pertinent to each theory. If courts can follow these simple prescriptions, we will have come a long way toward calming the tumultuous sea of First Amendment doctrine.

89. See, e.g., Denver Area Educ. Telecommunications Consortium, Inc. v. FCC, 518 U.S. 727, 785-86 (1996). 